\title{
STUDI PEMAHAMAN BUKTI DAN PEMBUKTIAN DALAM GEOMETRI EUCLID MAHASISWA JURUSAN TADRIS MATEMATIKA IAIN TULUNGAGUNG
}

\author{
Beni Asyhar \\ Jurusan Tadris Matematika, Institut Agama Islam Negeri (IAIN) Tulungagung \\ asyhar_beni@yahoo.com
}

\begin{abstract}
One of the problems to be solved in mathematics is a proof. At the college level, proving to be more important than the previous levels. When someone has a hunch about something (theorem), one of the most appropriate way to ensure that something (theorem) is true is by proving mathematically valid (formally). That is, the truth of the theorem is based on logical statements. However, proof of this is a problem when introduced during the learning. Not only the beginning students, final year students, moreover those already graduated are still experiencing difficulties in proving. This study attempts to describe the understanding of the concept of proof in mathematics and describes the ability of students in validating and compiling of proof in mathematics, particularly in Euclidean geometry using qualitative research approach, the type of case studies.
\end{abstract}

Keywords: Understanding, Proof, Proving, Euclid Geometry

\section{PENDAHULUAN}

Salah satu masalah yang harus diselesaikan dalam matematika adalah masalah pembuktian. Menurut Polya, masalah pembuktian nampak lebih penting pada matematika tingkat perguruan tinggi dibandingkan dengan tingkat-tingkat sebelumnya (Polya, 1981). Ketika seseorang mempunyai dugaan tentang suatu hal (teorema), salah satu cara yang paling tepat untuk meyakinkan bahwa hal (teorema) tersebut benar adalah dengan melakukan pembuktian matematis yang sah (secara formal). Proses mendefinisikan pembuktian ini berkembang dari masa ke masa sesuai dengan perkembangan zaman. Untuk memahami suatu penjelasan maka dibutuhkan pembuktian yang dilakukan sesuai definisi dan aksioma yang berlaku. Dengan cara menyatukan beberapa konsep secara utuh, hal ini akan memperbaiki atau mempertahankan argumen yang telah dikemukakan. Jelaslah saat ini memperhatikan penalaran dan pembuktian dalam matematika sangat penting karena dalam memahami suatu kebenaran yang telah ditemukan atau sebelumnya telah dibuktikan.

Berdasarkan hasil penelitian yang dilakukan oleh Arnawa diperoleh informasi bahwa mahasiswa yang memperoleh pembelajaran khusus tentang pembuktian dalam matematika (materi Aljabar Abstrak berdasarkan teori APOS) mempunyai kemampuan memvalidasi bukti lebih baik secara signifikan jika dibandingkan dengan mahasiswa yang memperoleh pembelajaran secara konvensional (Arnawa, 2009). Hal ini berarti bahwa mahasiswa yang tidak mendapat perhatian khusus dalam hal pembuktian matematika cenderung rendah kemampuannya dalam melakukan pembuktian. Begitu juga pada saat peneliti melakukan studi pendahuluan tentang pemahaman mahasiswa tentang konsep bukti dan pembuktian dalam matematika, beberapa mahasiswa Jurusan Tadris Matematika (TMT) IAIN Tulungagung menyampaikan bahwa dalam melakukan pembuktian cenderung kesulitan menemukan ide untuk memulai dari mana, mau diapakan, dan menggunakan cara yang mana. Mahasiswa masih kesulitan menentukan apa yang diketahui, apa yang ditanyakan atau apa yang akan dibuktikan, dan bagaimana memulai menyusun bukti tersebut.

Kesulitan yang dialami oleh mahasiswa memang ada yang mempengaruhi. Didasarkan pada konstruksi "skema pembuktian" (Harel \& Sowder, 1998), Harel dan Sowder mengeneralisasikan suatu 
perspektif komprehensif pada pengajaran dan pembelajaran bukti yang terdiri dari berbagai faktor, yaitu: matematika dan history-epistemologi, kognitif, dan pembelajaran sosio-cultural (Harel \& Sowder, 2007). Pada umumnya, penelitian empiris berfokus pada faktor kognitif dengan menganalisis jawaban-jawaban mahasiswa terhadap pertanyaan pembuktian. Selain itu, konsep yang dimiliki oleh mahasiswa tentang pembuktian juga mempengaruhi pendekatan yang mereka gunakan untuk berargumentasi dan membuktikan (Healy \& Hoyles, 2000).

Berdasarkan pentingnya memahami konsep bukti dan pembuktian dalam matematika, hasil penelitian terdahulu, dan kondisi di lapangan yang telah dipaparkan sebelumnya, dengan mempertimbangkan kemampuan yang dimiliki mahasiswa tentang pemahaman konsep bukti dan pembuktian dalam matematika, maka perlu kiranya diteliti lebih lanjut mengenai kemampuan mahasiswa dalam memahami konsep bukti dan kemampuan mahasiswa dalam memvalidasi bukti matematika serta kemampuan mahasiswa dalam menyusun pembuktian dalam matematika sesuai pemahaman yang dimiliki oleh mahasiswa. Penelitian ini akan difokuskan pada pemahaman tentang konsep bukti dan pembuktian dalam Geometri Euclid. Dengan adanya penelitian ini, diharapkan dapat mendeskripsikan pemahaman mahasiswa tentang konsep bukti dan pembuktian dalam Geometri Euclid.

\section{KAJIAN TEORI \\ Pengertian Tentang Pemahaman Mahasiswa}

Kata paham atau mengerti adalah satu kata yang sangat sering diucapkan dalam proses pembelajaran matematika di dalam kelas. Dosen mengkoordinir berbagai kegiatan dan memfasilitasi berbagai proses pembelajaran dengan tujuan mahasiswa memahami apa yang ingin disampaikannya sejalan dengan rencana pembelajaran yang telah dipersiapkan sebelumnya. Pertanyaan "Apakah kalian sudah mengerti?", “Apakah kalian sudah paham?” sering diucapkan oleh guru atau dosen tanpa adanya rasa bosan. Pertanyaan tersebut digunakan oleh seorang guru atau dosen dalam rangka untuk memeriksa efektivitas kegiatan proses pembelajaran di dalam kelas.

Banyak ahli dan praktisi pendidikan yang membahas tentang pemahaman konsep matematika. Skemp (1976) membedakan pemahaman ini menjadi dua bagian, yaitu: "instrumental understanding" (pemahaman instrumental) dan "relational understanding" (pemahaman relasional). Pemahaman instrumental mengacu pada aturan-aturan tanpa alasan, yaitu kemampuan menggunakan aturan-aturan matematis tanpa menyadari alasan penggunaan aturan tersebut. Namun kemudian pemahaman ini disanggahnya dengan menuliskan kembali pada artikel yang sama bahwa, "Instrumental understanding I would until recently not have regarded as understanding at all". Skemp melihat bahwa pemahaman instrumental bukanlah pemahaman konsep yang sesungguhnya, karena kebanyakan orang yang menyebut diri mereka memiliki pemahaman ini hanya menggunakan aturan tanpa alasan dan memiliki kemampuan untuk menggunakannya karena mereka memang mengingat cara untuk melakukannya. Pemahaman relasional mengacu pada mengetahui apa yang harus dilakukan dan mengapa melakukannya. Pemahaman inilah yang dimaksud Skemp, termasuk pada penelitian ini, sebagai pemahaman sesungguhnya.

Pemahaman adalah suatu aspek dari hidup seseorang; merupakan suatu pernyataan mental; atau merujuk pada kapasitas seseorang untuk bertindak dengan cara yang sesuai dan mengindikasikan pemahaman yang dimilikinya (Porteous, tt). Pernyataan mental seseorang akan suatu konsep (matematis) sangat dipengaruhi oleh pengetahuannya tentang konsep tersebut. Pengetahuan ini merupakan hasil pengalaman yang didapat secara sengaja maupun tidak sengaja selama kurun waktu kehidupannya. Pengetahuan atau pemahaman ini dimulai dengan benda atau peristiwa nyata yang dialami dan informasi yang diterimanya dalam kehidupan sehari-hari. Pemahaman ini kemudian termodifikasi menjadi pemahaman yang formal dan sengaja dibentuk oleh adanya pendidikan matematika yang diterimanya di sekolah.

Pemahaman seseorang erat kaitannya dengan pengalaman atau informasi yang diterimanya. Pengalaman dan informasi tersebut sebagian besar diperoleh dari proses belajar mengajar di sekolah atau di kampus. Pada dasarnya sebagian besar kegiatan di kelas memang bertujuan untuk membuat mahasiswa mengingat apa yang telah dipelajari. Namun dengan adanya pemahaman, usaha untuk mengingat menjadi berkurang karena pemahaman membentuk suatu kesatuan konsep yang tersimpan dalam otak yang sewaktu-waktu dapat diakses kembali sesuai dengan kebutuhan. Hal ini sejalan 
dengan pendapat Cockcroft (1986) yang menyebutkan bahwa pemahaman konsep matematis merupakan isyarat dari suatu kemampuan untuk mengenali dan memanfaatkan suatu konsep matematis dalam berbagai macam keadaan, mencakup beberapa hal yang tidak dikenal secara umum.

Pemikiran lain mengenai pemahaman disampaikan oleh Haylock dalam Porteous (tt). Ia berpendapat bahwa " ... to understand something means to make (cognitive) connections" . Memahami sesuatu berarti membuat koneksi kognitif . Koneksi yang dimaksud adalah situasi konkret, gambar, simbol, dan bahasa matematis. Memahami sesuatu berarti juga membuat koneksi antara pengalaman atau informasi yang baru saja diterimanya dengan pemahaman atau pengetahuan yang telah ada sebelumnya. Hal ini sejalan dengan pendapat Nickerson dalam Barmby, et. all (2007) yang menyebutkan bahwa pemahaman dalam kehidupan sehari-hari dapat ditingkatkan dengan kemampuan untuk membangun jembatan antara satu konsep dengan konsep lainnya. Semakin banyak pengetahuan seseorang, semakin baik orang tersebut dalam memahaminya. Semakin kaya konteks konseptual yang dapat dikaitkan seseorang pada sebuah fakta baru, maka semakin layak orang tersebut dikatakan mengerti akan fakta tersebut.

Alfeld (2004) mengatakan bahwa seseorang dikatakan memahami suatu konsep matematika jika dapat melakukan hal-hal berikut ini:

a. Menjelaskan konsep dan fakta matematika dengan cara yang lebih sederhana.

b. Membuat koneksi logis dengan mudah antara fakta dan konsep yang berbeda.

c. Mengenali koneksi ketika dihadapkan pada sesuatu yang baru (di dalam atau di luar matematika) yang berkaitan dengan konsep matematis yang dipahami.

d. Mengidentifikasi prinsip-prinsip suatu konsep matematis yang dapat membuat semuanya bekerja dengan baik.

Pemahaman tidak dapat ditransfer dari siapapun. Setiap orang memahami apa yang dihadapi atau dialaminya dengan cara yang unik. Kegiatan yang sama dan perlakuan yang sama di dalam kelas tidak menjamin akan membentuk kemampuan yang sama pada setiap mahasiswa. Mereka menyerap pelajaran sesuai dengan pengetahuan awal yang mereka miliki dan mengoneksikannya dengan pengalaman yang baru mereka terima di sekolah atau di kampus. Dosen dalam kelas bertugas untuk memfasilitasi mahasiswa dalam rangka mencapai pemahaman yang seharusnya ditangkap mahasiswa selama pembelajaran.

Pemahaman tidak dapat diamati secara langsung oleh guru atau dosen karena pemahaman adalah suatu sikap pandang internal yang harus dicapai secara individu oleh masing-masing peserta didik (Cockcroft, 1986). Dengan kata lain guru atau dosen tidak dapat benar-benar mengukur sejauh apa pemahaman peserta didik yang sesungguhnya. Kita hanya perlu mendapatkan penjelasan yang lebih baik tentang pemahaman ini. Akan tetapi, pengukuran ini sangat penting untuk menilai sejauh apa pemahaman yang dimiliki seorang peserta didik dan sebagai feedback sejauh mana keberhasilan pembelajaran yang dilakukan guru atau dosen. Perlu adanya suatu batasan atau standar yang dibuat untuk mengetahui sejauh mana pemahaman seorang peserta didik. Michener mengatakan bahwa pemahaman matematika adalah suatu proses yang dapat dipahami dan mencapai taraf tertentu dari bahan yang sudah diajarkan (Michener, 1978). Hal ini berarti peserta didik dianggap paham jika telah menyerap suatu konsep matematis tertentu yang telah dibatasi dan ditetapkan dalam suatu pembelajaran matematika.

Memang tidak mungkin seorang mahasiswa dapat memahami satu materi tertentu secara tuntas, namun pemahaman yang dimaksud dalam penelitian ini adalah pemahaman pada level tertentu. Hal ini sejalan dengan pendapat Barmby, et. all. (2007) bahwa seseorang tidak akan pernah mendapatkan pemahaman yang komplet, karena pemahaman tersebut dapat terus dikembangkan dengan membuat lebih banyak kaitan (link) terhadap apa yang telah dipahami sebelumnya. Pemahaman seseorang akan suatu konsep adalah sesuatu yang abstrak dan bersifat internal, sehingga sulit untuk mengukur dengan tepat bagaimana pemahaman sebenarnya dari seseorang. Namun demikian, Hiebert dan Carpenter (1992) dalam Barmby, et. all. (2007) menawarkan metode untuk mengukur (menilai) pemahaman seseorang dengan menganalisis:

a. Students' errors (kesalahan yang dilakukan mahasiswa).

b. Koneksi yang dibuat antara simbol dan prosedur simbolis dan representasi yang bersesuaian.

c. Koneksi yang dibuat antara prosedur simbolis dan situasi pemecahan masalah informal (seharihari).

d. Koneksi yang dibuat antara sistem-sistem simbol yang berbeda. 
Pemahaman mahasiswa dapat diukur dengan melihat seberapa banyak kesalahan yang dilakukan mahasiswa. Memang mahasiswa sering memberikan jawaban yang benar walaupun mereka tidak memahami apa yang mereka kerjakan. Barmby, et. all. (2007) mengatakan bahwa: "The fact that a student gets a calculation correct tells us little about the extent of their understanding. However, when a student makes a mistake in a calculation, then this might indicate the limitations of their understanding, even if that understanding is only instrumental". Apabila kesalahan yang dilakukan mahasiswa sedikit bukan berarti menunjukkan bahwa mereka memahami apa yang dikerjakan. Namun, jika kesalahan yang mereka lakukan begitu banyak, ini mengindikasikan bahwa pemahaman mereka masih rendah.

Berdasarkan berbagai pendapat di atas, dapat disimpulkan bahwa pemahaman matematika merupakan suatu pernyataan mental seseorang berdasarkan pengalaman dan pengetahuan tentang konsep matematis yang diperoleh sebelumnya dan kemampuan membuat koneksi berbagai konsep tersebut untuk memahami situasi atau fakta baru, menyelesaikan permasalahan, atau memperkaya pemahaman sebelumnya. Pemahaman konsep matematis ini terintegrasi dan tersusun dalam pikiran setiap mahasiswa. Mahasiswa mengetahui apa yang harus dilakukan dan mengapa melakukan hal tersebut dengan mengakses kembali konsep matematis tersebut dan merekonstruksinya kembali jika mereka lupa pada saat dihadapkan dengan permasalahan.

Berdasarkan pemahaman dari uraian di atas, penelitian ini memfokuskan pengamatan pemahaman konsep bukti mahasiswa yang mencakup kemampuan untuk menyerap atau memahami ide atau konsep matematis tentang Geometri Euclid dan kemampuan mengaplikasikan konsep secara benar dan tepat pada pemecahan masalah, yaitu memahami kaidah-kaidah dan prosedur pembuktian dalam matematika.

\section{Pengertian Bukti dan Pembuktian dalam Matematika}

Sebelum membahas pembuktian, ada baiknya jika membahas definisi bukti dalam matematika terlebih dahulu. Belum ada definisi yang tepat mengenai bukti formal dalam matematika. Sampai saat ini masih terdapat perbedaan pendapat, tergantung pada sudut pandang tertentu. Berikut ini beberapa pendapat mengenai bukti formal dalam matematika.

Kassios (2009) menyatakan bahwa bukti formal bukanlah suatu argumen bahasa natural. Hal ini adalah perhitungan yang mengikuti aturan-aturan yang tepat. Mengikuti aturan-aturan yang tepat ini merupakan inti dari metode formal. Sebagai pengganti dari penggunaan bahasa natural (informal) untuk alasan tentang kebenaran suatu program (pernyataan), digunakan notasi-notasi formal yang rigor (ketat), tidak ambigu (jelas), dan dapat diperiksa secara mekanis.

Hanna dalam Vanspronsen (2008) menyatakan bahwa bukti matematis diperoleh dari sekumpulan pernyataan eksplisit (seperti aksioma, prinsip-prinsip yang diterima, atau hasil yang sudah dibuktikan sebelumnya) kemudian menggunakannya, dengan menerapkan prinsip-prinsip logika untuk membentuk sebuah argumen deduktif yang sahih. Lebih lanjut, Hanna dan Barbeau dalam Vanspronsen (2008) menyatakan bahwa bukti adalah serangkaian jumlah hingga dari langkahlangkah logika dari apa yang diketahui menuju suatu kesimpulan menggunakan aturan-aturan inferensia. Bukti merupakan serangkaian argumen yang disusun logis untuk menjelaskan kebenaran suatu pernyataan (teorema).

Berdasarkan beberapa definisi bukti tersebut dapat dipahami bahwa bukti dalam matematika merupakan suatu tugas matematika yang dalam hal ini mahasiswa disediakan beberapa informasi awal tentang pernyataan yang akan dibuktikan tersebut, seperti: asumsi, aksioma, definisi; dan diminta untuk menerapkan aturan inferensia (menggunakan fakta-fakta sebelumnya, menerapkan teorema) sampai diperoleh kesimpulan yang diharapkan. Selain itu, dapat ditentukan mengenai ciri-ciri dari bukti formal, yaitu: 1) menggunakan notasi-notasi formal, yaitu: melibatkan variabel, operator logika, kesamaan, dan kuantor; 2) Logika yang dibangun harus ketat (rigor), tidak ambigu, menerapkan dan menggunakan prinsip logika (inferensia), dapat divalidasi secara mekanistis; dan 3) Menyusun bukti menggunakan pernyataan-pernyataan yang logis. Pernyataan-pernyataan ini dapat berasal dari premis pernyataan itu sendiri, teorema-teorema lainnya, definisi, dan dapat berasal dari postulat di mana sistem matematika tersebut berasal. Pentingnya bukti matematika yaitu untuk meyakinkan bahwa apa yang selama ini dianggap benar adalah memang benar.

Selanjutnya akan dibahas mengenai pembuktian dalam metamatika. Pembuktian pada dasarnya adalah membuat serangkaian deduksi dari asumsi (premis atau aksioma) dan hasil-hasil 
matematika yang sudah ada (lemma atau teorema) untuk memperoleh hasil-hasil penting dari suatu persoalan matematika (Tall, 1989). Satu-satunya yang dapat menjamin kebenaran dari suatu pernyataan matematika adalah dengan bernalar secara deduktif (Rich \& Thomas, 2009). Pembuktian yang diperoleh melalui bernalar secara deduktif dimaksudkan untuk menetapkan kepastian dari pengetahuan matematika, tetapi kepastian itu tidaklah absolut.

Berdasarkan perspektif perkembangan kognitif, Tall menjelaskan bahwa representasi bukti berkembang melalui empat tahapan, yaitu: bukti enaktif (enactive proof), bukti visual (visual proof), bukti simbolik (symbolic proof), dan bukti formal (formal proof) (Tall, 1995). Bukti enaktif, melibatkan peragaan fisik untuk menunjukkan suatu kebenaran; bukti visual, melibatkan pembuatan grafik atau gambar; bukti simbolik, melibatkan pemanipulasian simbol-simbol aljabar; dan bukti formal melibatkan penalaran deduktif.

Metode pembuktian dikembangkan bertujuan untuk meningkatkan kemampuan mahasiswa dalam memahami pembuktian, dan mengerjakan (membuktikan) suatu pernyataan matematik. Berbagai pendekatan dan metode telah dikembangkan, di antaranya Tall (1998) menyarankan konsep bukti generik sebagai cara untuk meningkatkan pemahaman mahasiswa terhadap bukti suatu pernyataan. Bukti generik diberikan dalam level contoh yang menjelaskan konsep secara umum dengan memandang contoh khusus. Hal ini tentu saja berbeda dengan pembuktian secara umum yang mensyaratkan abstraksi dengan level yang lebih tinggi. Kemudian, Leron dalam Tall (1998) mengajukan bukti terstruktur dengan sifat menggabungkan metode penyajian formal dan informal ke dalam suatu pembuktian. Tujuan utama dari bukti terstruktur ini bukan untuk meyakinkan, tetapi untuk membantu pembaca dalam meningkatkan pemahamannya terhadap gagasan di belakang bukti itu, dan bagaimanakah hubungannya dengan hasil-hasil matematika lainnya.

\section{METODE PENELITIAN}

Penelitian ini menggunakan pendekatan kualitatif, jenis studi kasus. Subyek penelitian ini adalah mahasiswa S-1 Jurusan Tadris Matematika IAIN Tulungagung. Pemilihan subyek didasarkan pada kriteria sebagai berikut: 1) mahasiswa aktif S-1 TMT IAIN Tulungagung, 2) minimal semester IV (sudah menempuh mata kuliah Pengantar Logika dan sudah atau sedang menempuh mata kuliah Geometri Euclid), dan 3) mampu berkomunikasi dengan baik dalam bentuk lisan atau tulisan. Berdasarkan hasil pemilihan subyek, diperoleh MS dan DJE sebagai subyek berkemampuan tinggi, ARR dan SK sebagai subyek berkemampuan sedang, kemudian UNH dan RH sebagai subyek berkemampuan rendah. Instrumen penelitian dalam penelitian ini adalah: 1) peneliti sebagai instrumen, 2) pedoman observasi, 3) pedoman wawancara, 4) pedoman dokumentasi, dan 5) lembar tugas. Sedangkan teknik pengumpulan datanya menggunakan observasi, wawancara, dan dokumentasi. Analisis data dalam penelitian ini dilakukan sejak sebelum memasuki lapangan, selama di lapangan, dan setelah selesai di lapangan. Peneliti menggunakan 3 tahapan dalam melakukan analisis data, yaitu: reduksi data, penyajian data, dan penarikan kesimpulan dan verifikasi.

\section{PEMBAHASAN}

\section{Pemahaman Mahasiswa Tentang Konsep Bukti dalam Matematika}

Berdasarkan data hasil penelitian, pemahaman mahasiswa tentang konsep bukti dalam matematika masih jauh dari harapan. Mahasiswa masih lemah dalam memahami hal-hal yang berhubungan dengan bukti atau pembuktian dalam matematika. Seperti diketahui bahwa bukti merupakan serangkaian argumen yang disusun logis untuk menjelaskan kebenaran suatu pernyataan (teorema). Hal ini sesuai dengan pendapat Hanna dan Barbeau dalam Vanspronsen (2008) yang menyatakan bahwa bukti adalah serangkaian jumlah hingga dari langkah-langkah logika dari apa yang diketahui menuju suatu kesimpulan menggunakan aturan-aturan inferensia. Aturan-aturan inferensia yang dimaksud adalah aturan yang nilai kebenarannya sudah diketahui valid.

Mahasiswa memahami bukti itu merupakan suatu himpunan pernyataan yang disusun untuk menentukan kebenaran suatu pernyataan (teorema) dalam matematika. MS mengatakan bahwa bukti dalam matematika adalah konsep dasar untuk mengetahui bahwa suatu teorema itu valid atau tidak valid. DJE mengatakan bahwa pembuktian dalam matematika adalah membuktikan suatu pernyataan (teorema) dalam matematika dengan cara cara langsung maupun tidak langsung. ARR memahami bukti sebagai suatu konsep atau landasan yang mampu menjadikan suatu teorema terbukti dengan langkah-langkah membawa aksioma, definisi, dan lain-lain. Lebih lanjut, SK memahami bukti dalam 
matematika tentu harus dikembalikan kepada teorema-teorema, definisi yang sudah diketahui yang kemudian diselesaikan menggunakan cara-cara tertentu. Sedangkan UNH memahami bukti dalam matematika dapat dilakukan secara langsung membuktikan dengan urutan pernyataan dan secara tidak tidak langsung dapat dilakukan dengan kontradiksi dan kontrapositif. Menurut RH, bukti dalam matematika adalah pembuktian benar atau salahnya suatu pernyataan secara umum dalam bidang matematika.

Berkaitan dengan pemahaman konsep bukti, ada beberapa hal yang harus dipahami sebelum melakukan pembuktian, yaitu: definisi, kalimat tertutup, pernyataan, proposisi, premis, hipotesis, konklusi, aksioma, postulat, teorema, lemma, dan corollary. Tidak semua subyek penelitian memahami beberapa istilah yang sering digunakan untuk menyusun bukti suatu pernyataan. Terutama lemma dan corollary, hanya UNH yang mampu menjelaskan bahwa lemma adalah teorema yang terbatas/semi teorema yang cakupannya lebih kecil dibandingkan teorema dan corollary adalah akibat langsung dari suatu teorema.

Berdasarkan data hasil penelitian, 3 orang subyek penelitian sudah memahami bahwa definisi adalah uraian pengertian yang berfungsi untuk membatasi objek, konsep, dan keadaan berdasarkan waktu dan tempat suatu kajian, yaitu: DJE, ARR, dan UNH. Sedangkan MS, SK, dan RH masih memahami definisi sebagai pernyataan yang tidak perlu dibuktikan.

Selanjutnya, kalimat tertutup, pernyataan, dan proposisi masih dianggap sesuatu yang berbeda. Padahal ketiga istilah tersebut merupakan sesuatu yang sama atau memiliki arti yang sama. Kalimat tertutup, pernyataan, dan proposisi merupakan kalimat deklaratif yang bernilai benar atau salah, tetapi tidak keduanya (Marsudi, 2010). Istilah yang digunakan dalam literatur buku berbedabeda, tergantung kepada penulis buku tersebut, ada yang menggunakan istilah kalimat tertutup, pernyataan, atau proposisi.

Berdasarkan beberapa pendapat yang disampaikan oleh subyek penelitian, hanya SK dan RH yang mengetahui definisi premis. MS mengatakan bahwa premis merupakan pernyataan primitif atau pernyataan asal. DJE mengatakan bahwa premis adalah pernyataan, baik tunggal yang dilengkapi dengan perangkai logika. ARR memahami premis sebagai pernyataan sebab akibat yang perlu dibuktikan kebenarannya. Kemudian SK memahami premis sebagai pernyataan yang jika dihubungkan dengan pernyataan lain menggunakan hukum-hukum logika, maka akan diketahui nilai kebenarannya. Selanjutnya, premis menurut UNH adalah pernyataan sedangkan menurut RH, premis merupakan pernyataan yang digunakan sebagai dasar penarikan kesimpulan.

Secara umum, mahasiswa sudah memahami bahwa hipotesis adalah kesimpulan awal/dugaan awal (apa yang diketahui) dan konklusi adalah kesimpulan (apa yang akan dibuktikan), yaitu pernyataan/informasi baru yang didapatkan dari sintesis premis-premis. Dari 6 subyek penelitian, 5 subyek dapat menjelaskan definisi dari hipotesis dan konklusi. Hanya RH yang belum mampu menjelaskan definisi dari hipotesis dan konklusi.

Berdasarkan data hasil penelitian, semua subyek penelitian menganggap bahwa aksioma dan postulat adalah sesuatu yang sama. Memang, aksioma dan postulat merupakan pernyataan yang tidak perlu dibuktikan kebenarannya karena sudah disepakati benar. Akan tetapi pada prakteknya, aksioma digunakan untuk matematika secara umum, sedangkan postulat lebih khusus di geometri.

\section{Kemampuan Mahasiswa dalam Memvalidasi Bukti Suatu Pernyataan (Teorema) dalam Geometri Euclid}

Belum ada formula khusus yang disepakati oleh pada ilmuwan yang bergelut di dunia matematika dan pendidikan matematika untuk mendefinisikan bukti matematis. Oleh karena itu, membuktikan suatu pernyataan (teorema) merupakan masalah tersendiri. Mengkonstruksi dan menuliskan suatu bukti serta memvalidasi kebenaran suatu bukti merupakan masalah yang sering muncul pada saat dihadapkan dengan pembuktian.

Berdasarkan data hasil penelitian, kemampuan mahasiswa dalam memvalidasi bukti suatu pernyataan (teorema) dalam Geometri Euclid masih belum memenuhi harapan peneliti. Pada penelitian ini mahasiswa diharapkan dapat mengecek kebenaran bukti suatu pernyataan (teorema) berikut: "Jika dua sudut suatu segitiga kongruen, maka sisi-sisi di hadapan sudut-sudut tersebut kongruen." Mahasiswa masih belum mampu memvalidasi kebenaran suatu teorema. Dari 6 subyek penelitian, sebanyak 3 subyek mengatakan bukti yang diberikan sudah benar dan 3 sisanya mengatakan bahwa bukti yang diberikan masih salah. 
Keenam subyek penelitian berbeda-beda dalam memvalidasi kebenaran teorema tersebut. Pertama, MS mengatakan bahwa bukti yang diberikan benar. MS kurang teliti dalam mengecek kebenaran suatu pernyataan. MS juga tidak teliti dengan pernyataan-pernyataan yang diketahui. Kedua, DJE juga mengatakan bahwa bukti yang diberikan benar. Sama halnya dengan MS, DJE juga kurang teliti dalam mengecek kebenaran suatu pernyataan. Akan tetapi DJE lebih teliti dibandingkan MS dalam menyusun pernyataan-pernyataan yang diketahui. Kemudian yang dijadikan dasar dalam menganalisis pernyataan-pernyataan yang diketahui adalah gambar yang ada pada lembar tugas. Akibatnya, pernyataan-pernyataan yang disusun tersebut tidak akan memperoleh kesimpulan yang benar. Ketiga, ARR juga mengatakan bahwa bukti yang diberikan benar. ARR kurang teliti dalam mengecek kebenaran suatu pernyataan. Sama halnya dengan MS dan DJE yang juga kurang teliti dalam mengecek kebenaran suatu pernyataan. Keempat, KS mengatakan bahwa bukti yang diberikan salah. Hal ini berarti KS sudah teliti dalam mengecek kebenaran suatu pernyataan. KS sudah dapat mengidentifikasi kesalahan bukti yang diberikan, namun belum mampu memberikan masukan bukti yang benar. Justru KS menggunakan pernyataan-pernyataan yang salah sebelumnya untuk menyusun bukti yang benar. KS belum konsisten dalam memberikan penjelasan kebenaran suatu pernyataan. Kelima, mengatakan bahwa bukti yang diberikan salah. UNH sudah teliti dalam mengecek kebenaran suatu pernyataan, namun belum mampu memberikan masukan bukti yang benar. Justru UNH melakukan kesalahan dengan menggunakan pernyataan-pernyataan yang salah sebelumnya untuk menyusun bukti yang benar. Ketujuh, RH mengatakan bahwa bukti yang diberikan salah. RH belum teliti dalam mengecek kebenaran suatu pernyataan. RH menganggap pernyataan yang diberikan salah, bukan buktinya yang salah. RH salah dalam mengaplikasikan teorema sebelumnya yang mengatakan bahwa jika dua sudut suatu segitiga kongruen, maka sudut yang lain kongruen. Pada awalnya peneliti mengira bahwa RH menganggap pernyataan yang dibuktikan salah, akan tetapi setelah dilakukan wawancara diagnostik, RH mengatakan bahwa pernyataannya yang salah, bukan buktinya.

\section{Kemampuan Mahasiswa dalam Melakukan Pembuktian Suatu Pernyataan (Teorema) dalam Geometri Euclid}

Berdasarkan data hasil penelitian, kemampuan mahasiswa dalam melakukan pembuktian suatu pernyataan (teorema) dalam Geometri Euclid masih belum memenuhi harapan peneliti. Pada penelitian ini mahasiswa diharapkan dapat menunjukkan atau membuktikan kebenaran suatu pernyataan (teorema) berikut: "Jika garis-berat pada sisi-sisi suatu segitiga bertemu di satu titik, maka jarak dari titik sudut-titik sudut segitiga ke titik pertemuan tersebut adalah sama." Mahasiswa masih belum mampu membuktikan kebenaran suatu teorema secara lengkap. Dari 6 subyek penelitian, hanya 1 subyek saja yang mampu menyusun pernyataan-pernyataan yang logis dan disertai alasan yang lengkap, 2 subyek sudah mampu menyusun pernyataan-pernyataan yang logis tetapi belum disertai alasan yang lengkap, 2 subyek salah menerjemahkan penyataan ke dalam bentuk gambar, dan 1 subyek belum mampu menyelesaikan bukti tersebut.

Pertama, MS masih salah dalam menerjemahkan pernyataan yang diberikan ke dalam bentuk gambar. Dengan kata lain, MS masih belum mampu menguasai dengan baik cara memvisualisasikan suatu pernyataan ke bentuk gambar. Akibatnya, pernyataan-pernyataan yang disusun tidak memperoleh kesimpulan yang benar. Kedua, DJE sudah dapat menerjemahkan atau memvisualisasikan pernyataan yang diberikan ke dalam bentuk gambar. Argumen-argumen yang disusun untuk memperoleh kesimpulan sudah menggunakan pernyataan-pernyataan yang logis. Akan tetapi alasan yang diberikan belum lengkap. Ketiga, ARR sudah dapat menerjemahkan atau memvisualisasikan pernyataan yang diberikan ke dalam bentuk gambar. Argumen-argumen yang disusun untuk memperoleh kesimpulan sudah menggunakan pernyataan-pernyataan yang logis. Akan tetapi alasan yang diberikan belum lengkap. Keempat, KS sudah dapat menerjemahkan atau memvisualisasikan pernyataan yang diberikan ke dalam bentuk gambar. Akan tetapi belum teliti dalam menyusun pernyataan berdasarkan gambar yang dibuat sebelumnya. Akibatnya, pernyataanpernyataan yang disusun tidak memperoleh kesimpulan yang benar. Kelima, UNH sudah dapat menerjemahkan atau memvisualisasikan pernyataan yang diberikan ke dalam bentuk gambar. UNH juga mampu menyususn bukti pernyataan tersebut dengan menyusun pernyataan-pernyataan yang logis berdasarkan definisi, postulat, atau teorema-teorema sebelumnya untuk memperoleh kesimpulan yang benar. Keenam, RH dapat menerjemahkan atau memvisualisasikan pernyataan yang diberikan ke 
dalam bentuk gambar. Akan tetapi belum mampu menyusun buktinya dalam bentuk narasi atau pernyataan-pernyataan yang logis.

\section{Faktor-faktor yang Mempengaruhi Mahasiswa dalam Melakukan Pembuktian Suatu Pernyataan (Teorema) dalam Matematika}

Berdasarkan data hasil penelitian, ada beberapa faktor yang menyebabkan mahasiswa mengalami kesulitan dalam melakukan pembuktian suatu pernyataan (teorema) dalam matematika. Penyebab kesulitan tersebut cenderung berasal dari dalam diri mahasiswa sendiri dan juga ada yang disebabkan oleh faktor luar, seperti: proses pembelajaran, lingkungan belajar, dan metode pembelajaran. Faktor-faktor yang menjadi penyebab kesulitan tersebut dapat diuraikan sebagai berikut.

Pertama, keterbatasan penggunaan bahasa dan simbol matematika. Akibatnya, mahasiswa kesulitan memodelkan pernyataan dalam bentuk simbol dan tidak mampu mengidentifikasi apa yang diketahui, apa yang tanyakan, dan harus bagaimana membuktikannya. Kedua, kurang menguasai materi. Mahasiswa lupa dengan berberapa hal yang berkaitan dengan pernyataan tersebut, misalnya: definisi, teorema, aksioma, maupun postulat. Ketiga, kesulitan menyusun bukti dalam bentuk narasi. Mahasiswa sebenarnya dapat menjelaskan secara detail mengenai definisi, gambar yang dimaksud dalam pernyataan, dan juga dapat menjelaskan menggunakan teorema berdasarkan gambar tersebut, akan tetapi mahasiswa masih mengalami kesulitan untuk menyusun dalam bentuk pernyataanpernyataan yang logis (bentuk narasi). Mahasiswa cenderung dapat menjelaskan atau membuktikan secara informal, bukan formal. Keempat, kesulitan menentukan metode dalam membuktikan. Metode yang digunakan dalam proses pembuktian bermacam-macam, ada pembuktian langsung dan pembuktian tidak langsung. Kelima, proses pembelajaran yang belum mengarahkan kepada kemandirian mahasiswa dalam melakukan pembuktian. Dalam pembelajaran, pernyataan (teorema) yang ada dibuktikan secara terbatas. Kemudian tidak ada tuntutan kepada mahasiswa untuk membuktikan kebanaran teorema tersebut. Dan keenam, cenderung menghafal bukti. Kebanyakan mahasiswa masih menyukai metode hafalan. Mereka dapat membuktikan kebenaran suatu teorema karena sudah hafal cara membuktikannya. Kemampuan membuktikan tersebut bukan berasal dari pemahaman, akan tetapi karena hafalan saja. Mahasiswa merasa kesulitan untuk mengeluarkan ide pada saat dihadapkan dengan persoalan pembuktian yang baru.

\section{PENUTUP}

Berdasarkan hasil penelitian tentang pemahaman konsep bukti dan pembuktian dalam Geometri Euclid dapat disimpulkan sebagai berikut: 1) mahasiswa masih lemah dalam memahami hal-hal yang berhubungan dengan bukti atau pembuktian dalam matematika, 2) mahasiswa masih belum mampu menvalidasi dengan baik bukti suatu pernyataan (teorema) dalam Geometri Euclid, 3) mahasiswa masih belum mampu membuktian kebenaran suatu teorema secara formal dan lengkap, dan 4) faktor-faktor yang menyebabkan mahasiswa mengalami kesulitan dalam melakukan pembuktian adalah: (a) keterbatasan penggunaan bahasa dan simbol matematika, (b) kurang menguasai materi, (c) kesulitan menyusun bukti dalam bentuk narasi, (d) kesulitan menentukan metode dalam membuktikan, (e) proses pembelajaran yang belum mengarahkan kepada kemandirian mahasiswa dalam melakukan pembuktian, dan (f) cenderung menghafal bukti.

Berdasarkan hasil penelitian ini dapat diberikan saran sebagai berikut: 1) hendaknya hasil penelitian ini ditindaklanjuti dengan mengembangkan metode pembelajaran yang mengarahkan kepada kemandirian mahasiswa dalam memvalidasi bukti suatu pernyataan (teorema) dan melakukan pembuktian suatu pernyataan (teorema) secara formal, dan 2) hendaknya dalam pembelajaran, mahasiswa diberikan banyak contoh pernyataan (teorema) yang dibuktikan.

\section{DAFTAR RUJUKAN}

Alfeld, P. 2004. "Understanding Mathematics", (http://www.math.utah.edu/ pa/math. html, diakses 03 Oktober 2014)

Arnawa, I Made. 2009. "Mengembangkan Kemampuan Mahasiswa dalam Memvalidasi Bukti pada Aljabar Abstrak melalui Pembelajaran Berdasarkan Teori APOS", Jurnal Matematika dan Sains, Juni 2009, Vol. 14 No. 2 
Barmby, P., et. all, 2007, "How Can We Assess Mathematical Understanding?", dalam Proceedings of the $31^{\text {st }}$ Conference of the International Group for the Psychology of Mathematics Education, Vol. 2, pp. 41-48. Seoul: PME

Cockcroft, W. H. 1986. "Mathematics Counts", (http://www.educationengland.org.uk/documents/ cockcroft/cockcroft00.html, diakses 27 Januari 2012)

Harel, Guershon \& Larry Sowder. 1998. "Students' proof schemes: results from exploratory studies." In A.H. Schoenfeld, J. Kaput \& E. Dubinsky (Eds.), Research in collegiate mathematics education, 1998, Volume 3, pp.234-283, Mathematical Association of America

2007. "Toward the comprehensive perspectives on the learning and teaching of proof." In F. Lester (Ed.), Second handbook of research on mathematics teaching and learning, 2007, pp. 805-842, Charlotte, NC: Information Age Publishing

Healy, Lulu \& Celia Hoyles. 2000. “A study of proof conceptions in algebra”, Journal for Research in Mathematics Education, 2000, 31(4), 396-428.

Kassios, Y. 2009. "Formal Proof”, (http://www.cs.toronto.edu/ hehner/aPToP/formalproof-1.pdf, diakses tanggal 15 Oktober 2014)

Marsudi. 2010. Logika dan Himpunan. Malang: UB Press.

Michener, E. R. 1978. Understanding Understanding Mathematics. Cambridge, Massachusetts: Massachusetts Institute of Technology.

Polya, G. 1981. Mathematical Discovery: On Understanding, Learning and Teaching Problem Solving, Combined Edition. New York: John Willey \& Sons, Inc.

Porteous, K. tt. "Understanding Mathematics", (http://people.exeter.ac.uk/PErnest/pome23/ Porteous\%20Understanding\%20Mathematics.doc, diakses 03 Oktober 2014)

Rich, B. \& Christopher Thomas. 2009. Geometry: includes plane, analytic, and transformational geometries Fourth Edition. New York: McGraw-Hill Companies, Inc.

Skemp, Richard R. 1976. "Relational Understanding and Instrumental Understanding", (http://www.grahamtall.co.uk/skemp/pdfs/instrumental-relational.pdf, diakses 03 Oktober 2014)

Tall, D. 1989. "The Nature of Mathematical Proof”, dalam Mathematics Teaching, 127, hal. 23-32.

1995. Cognitive Development, Representations, and Proof, Makalah dipresentasikan pada Conference on Justifying and Proving in School Mathematics, Institute of Education, Desember 1995, London.

1998. The Cognitive Development of Proof: Is Mathematical Proof For All or Some? Conference of the University of Chicago School Mathematics Project.

Vanspronsen, H.D. 2008. Doctoral Dissertation: "Proof Processes Of Novice Mathematics Proof Writers." Missoula: University of Montana. 